\title{
Етапність в хірургічній тактиці при багаторівневих оклюзійно-стенотичних ураженнях черевної аорти та артерій нижніх кінцівок у хворих з облітеруючим атеросклерозом
}

\author{
А. М. Бицай \\ Національний інститут хірургії та трансплантології імені О. О. Шалімова НАМН України, м. Київ
}

\section{Stages in surgical tactics in multi-floor occlusive-stenotic affections of abdominal aorta and arteries of the lower extremities in patients, suffering obliterating atherosclerosis}

\author{
A. M. Bytsai \\ Shalimov National Institute of Surgery and Transplantology, Kyiv
}

\begin{abstract}
Реферат
Мета. Покращити результати хірургічного лікування хворих з багаторівневими оклюзійно-стенотичними ураженнями черевної аорти та артерій нижніх кінцівок (НК) на тлі критичної ішемії (КI).

Матеріали і методи. Проаналізовано результати хірургічного лікування 135 хворих з багаторівневими оклюзійними ураженнями та КІНК. До основної групи увійшли 68 (50,4\%) пацієнтів, яким виконали біфуркаційне аорто-стегнове алошунтування, поєднане зі стегно-підколінним шунтуванням, із застосуванням критерію - інтраопераційного визначення величини ретроградного кровообігу по глибокій артерії стегна (ГАС); до порівняльної групи - 67 (49,6\%) хворих, яким виконали стандартно той же об'єм реконструктивних операцій.

Результати. Аналіз результатів виконаних оперативних втручань засвідчив, що застосування, крім стандартних діагностичних методів: ультразвукового дуплексного сканування (УЗДС), артеріографії, мультиспіральної комп’ютерної томографії (МСКТ), інтраопераційної дебітометрії дає змогу об'єктивізувати стан ретроградного кровообігу та своєчасно коригувати об'єм та етапність хірургічного втручання. Завдяки цьому вдалося розширити показання до виконання одночасних багаторівневих реконструкцій черевної аорти та артерій НК без збільшення частоти як операційних, так і кардіологічних ускладнень.

Висновки. Застосування розробленого гемодинамічного критерію - визначення величини ретроградного кровотоку по ГАС 80 мл/хв - дало змогу оптимізувати хірургічну тактику та значно покращити результати хірургічного лікування. Призначення препарату «Валаргін» в дозі 3000 мг/добу протягом 20 діб покращувало ангіопротекцію в найближчому післяопераційному періоді.
\end{abstract}

Ключові слова: атеросклероз; оклюзія; шунтування; реконструкція.

Abstract

Objective. To improve the results of surgical treatment in patients with multi-floor occlusive-stenotic affections of abdominal aorta and arteries of the lower extremities on background of critical ischemia.

Materials and methods. The results of surgical treatment were studied in 135 patients with multi-level occlusive affections and critical ischemia of the lower extremities. There were 68 (50.4\%) patients in the main group, in whom a bifurcational aorto-femoral alloshunting, combined with femoro-popliteal shunting, using criterion - intraoperative determination of value of a retrograde blood circulation along a. femoris profunda (AFP). In a comparison group 67 (49.6\%) patients were included, in whom a standard volume of reconstructive operations was applied.

Results. Analysis of results of the operative interventions performed have witnessed, that application, besides a standard diagnostic methods, of ultrasound duplex scanning (USDS), arteriography, multispiral computed tomography (MSCT), intraoperative debitometry gave a possibility to objectivize a retrograde blood circulation state and timely correction of volume and a staged character of surgical intervention. Because of that, it was possible to dilate the indications for performance of simultaneous multi-level reconstruction of abdominal aorta and the lower extremities arteries without enhancement of rate of postoperative morbidity and cardiological complications.

Conclusion. Application of elaborated hemodynamical criterion for determination of value of retrograde blood flow along AFP $80 \mathrm{ml} / \mathrm{min}$ have permitted to optimize a surgical tactics and to improve the surgical treatment results significantly. Administration of «Valargin» preparation in a $3000 \mathrm{mg}$ /day dose during 20 days have improved the angioprotection in immediate postoperative period.

Keywords: atherosclerosis; occlusion; shunting; reconstruction.

Досі в судинній хірургії немає єдиної точки зору щодо етапності хірургічної тактики при багаторівневих ураженнях. Прихильники одномоментного багаторівневого «включення» в кровообіг декількох артеріальних басейнів констатують розвиток тяжких реперфузійних ре- акцій у 20 - 25\%, явищ гострого коронарного синдрому у 12 - 19\%, глибокого інфікування післяопераційних ран майже у $18 \%$ пацієнтів [1].

Прибічники етапного хірургічного лікування стверджують, що збільшення частоти розвитку тромбозу пер- 
винно реконструйованого артеріального сегмента в міжетапний період є наслідком високого периферичного опору у 20 - 25\% хворих у найближчому післяопераційному періоді [2]. Фактично четверта частина хворих не встигає дочекатись наступного хірургічного етапу за середнього строку його відтермінування 30 діб.

На практиці основним критерієм вибору хірургічної тактики є результати МСКТ, артеріографії та УЗДС, на підставі яких визначають зміни регіонарної гемодинаміки на доопераційному етапі. A. Bura Riviere і співавтори [3] вважають, що у 30 - 35\% хворих з багаторівневими оклюзійними ураженнями дистальне контрастування «шляхів відтоку» недостатньо об'єктивне з причини дефіциту колатеральних шляхів компенсації.

Тому однією з особливостей визначення тактичних підходів при багаторівневих ураженнях є інтраопераційне дослідження спроможності «шляхів відтоку» у поєднанні з даними МСКТ та УЗДС на доопераційному етапі. Завдяки саме інтраопераційному прямому визначенню показника ретроградного кровообігу по ГАС при оклюзії черевної аорти та поверхневих стегнових артерій А. Tanaka і співавтори [4] дійшли висновку, що виконання реконструкції стегнової артерії як доповнення до аорто-стегнового біфуркаційного шунтування у деяких хворих може обтяжувати їх стан та слугувати причиною тромбозу як стегно-підколінного шунта, так і бранші біфуркаційного протеза. Достатність ретроградного кровообігу по ГАС та ії адекватний зв'язок з підколінною артерією повністю виключає необхідність додаткової реконструкції стегно-підколінного сегмента.

У свою чергу D. G. Wilson і співавтори [2] вважають, що саме гемодинамічний удар у зоні анастомоза, коли діаметри судин не збігаються, має важливий вплив на активацію системної запальної відповіді та каталізує процес гіперплазії неоінтими. Тому гемодинамічне розвантаження анастомоза з браншею шляхом формування додаткового стегно-підколінного шунта має об'єктивну підставу. Загалом прихильники тактики одночасного багаторівневого втручання наводять аргументи, які грунтуються на зменшенні проявів системної запальної відповіді після виконання втручання.

Ці дані мають бути парадоксальними, адже і травма артеріальної стінки, і загальна хірургічна травма значно тяжчі у разі виконання одномоментних реконструкцій. Однак B. C. Branco і співавтори [1] отримали результати, що саме одночасне ефективне та радикальне втручання з приводу КІ тканин НК дає змогу значно зменшити концентрацію в крові маркерів системної запальної відповіді (ICAM та VCAM) у порівнянні з етапним лікуванням.

Тобто питання етапності та об'єму реконструктивного втручання є до сьогодні дискутабельним та не має чіткої відповіді у вигляді висновку за результатами рандомізованого клінічного дослідження або тези, сформованої ангіохірургічним консенсусом з теми хірургічної корекції КІ у хворих з багаторівневими ураженнями артеріального басейну НК.

Мета дослідження: покращити результати хірургічного лікування хворих з багаторівневими оклюзійно-стенотичними ураженнями черевної аорти та артерій НК на тлі КІ.

\section{Матеріали і методи дослідження}

Проведено ретро- та проспективний статистичний аналіз результатів 144 реконструктивних операцій, виконаних 135 хворим у відділенні хірургії магістральних судин Інституту. У всіх хворих діагностували КІНК згідно з класифікацією TASC II [5]. До протоколу стаціонарного обстеження було включено загальноклінічні дослідження, доплерографію, УЗДС, рентгенконтрастну артеріографію, МСКТ. Середній вік пацієнтів становив (70,8 4,1) року. Чоловіків було 121 (89,6\%), жінок - 14 (10,4\%). Тривалість захворювання становила в середньому $(13,8$ $\pm 2,6)$ міс. Середнє значення сегментарного тиску на НК дорівнювало $(27,6 \pm 7,4)$ мм рт. ст. Усіх хворих розподілили на дві групи - основну та порівняльну. Критерієм розподілу слугувало застосування інтраопераційного визначення ретроградного кровообігу по ГАС при багаторівневих оклюзійно-стенотичних ураженнях у хворих з облітеруючим атеросклерозом черевної аорти та НК на тлі КІ. До основної групи увійшло 68 (50,4\%) пацієнтів, яким виконали аорто-стегнове біфуркаційне алошунтування, поєднане зі стегно-підколінним шунтуванням, із застосуванням встановленого критерію за результатами дебітометрії. Порівняльну групу склали 67 (49,6\%) хворих, яким виконали стандартно аналогічне за об'ємом оперативне втручання. Тривалість міжетапного періоду (якщо втручання проводили неодночасно) становила в середньому $(32,5 \pm 10,2)$ доби. Хворі основної групи були оперовані в період з 2012 по 2016 р., порівняльної - з 2008 по 2012 р. Різниця в підходах до формування показань до операції полягала в тому, що в період 2012 - 2016 рр., крім загальноприйнятих критеріїв, для визначення стану регіонарної гемодинаміки використовували результати інтраопераційної дебітометрії, завдяки чому на інтраопераційному етапі коригували об'єм запланованого втручання саме у пацієнтів, які увійшли до основної групи.

Групи були статистично порівнянні за віком, тривалістю захворювання, гендерним показником, топографією оклюзійного процесу, рівнем хронічної артеріальної недостатності, тяжкістю супутньої патології, клінічними ознаками дисліпопротеідемії.

Критеріями включення пацієнтів до цього клінічного дослідження були: реконструктивна операція на черевній аорті та артеріях НК, стан «шляхів відтоку», оцінений у 7 - 8 балів за Рутерфордом, оклюзійно-стенотичне ураження черевної аорти (або обох здухвинних сегментів) з обов'язковим ураженням стегно-підколінного сегмента; КІНК; кількість лейкоцитів у крові не більше 12,0 × $10^{9}$ в 1 л; ШОЕ не більше 25 мм/год; концентрація ліпопротеїдів низької щільності у плазмі крові 2,5 - 4,0 ммоль/л.

Критеріями невключення були: наявність злоякісних новоутворень, декомпенсованої серцевої недостатності та цукрового діабету з нестабільною гіперглікемією; найближчі 3 міс після перенесеного інсульту та (чи) інфаркту; стан хворого, визначений як протипоказання до виконання реконструктивної операції на артеріях НК.

У післяопераційному періоді пацієнти основної групи приймали L-аргінін у вигляді препарату «Валаргін» («Валаргін Фарма») у дозі 3000 мг/добу протягом 20 діб як донатор NO задля стабілізації судинної стінки, особливо 


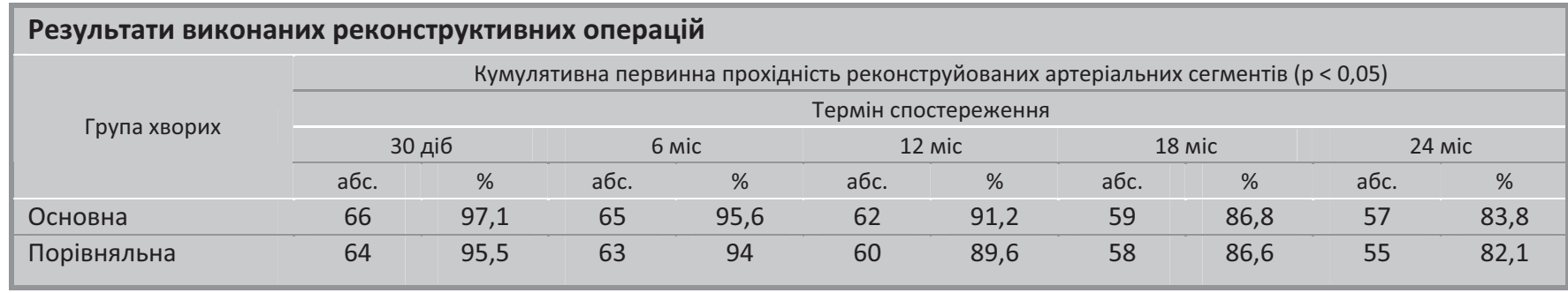

в зоні формування анастомозів у разі виконання багаторівневих втручань з метою профілактики гіперплазії неоінтими та позитивного впливу на реакції системної запальної відповіді.

Результати виконаних оперативних втручань аналізували згідно з рекомендаціями TASC II за бальною системою як у найближчому, так і у віддаленому періоді спостереження.

Для статистичної обробки результатів клінічного дослідження використовували програмне забезпечення Microsoft Excel 2010 (Microsoft, CШA), Statistica 10 (Statsoft, США) та R (Revolution Analytics, США). Групи хворих порівнювали за якісними показниками за допомогою критерію Фішера. Критичним рівнем значущості (р) під час перевірки статистичних гіпотез вважали значення менше 0,05.

\section{Результати}

Показання до виконання реконструктивних втручань були сформовані згідно з рекомендаціями TASC II, а саме у всіх пацієнтів діагностовано C та D типи оклюзійно-стенотичних уражень черевної аорти та артерій НК.

Диференціальним критерієм між двома групами було інтраопераційне визначення показника ретроградного кровообігу за допомогою дебітометрії. Якщо ретроградний кровообіг перевищував 80 мл/хв по ГАС, виконання додаткового стегно-підколінного шунтування слід відтермінувати. Цей показник-критерій визначили після «включення» бранші біфуркаційного аорто-стегнового алошунта в кровообіг. Вказане значення ретроградного кровообігу співвідноситься з лінійною швидкістю кровообігу (ЛшК) по бранші, не меншою за 0,7 м/с. Відомо, що саме така величина Лшк по бранші свідчить про задовільну пропускну здатність анастомозів. Визначення ретроградного кровообігу на доопераційному етапі в повній мірі неможливо через наявність периферичного судинного спазму, дифузного атеросклеротичного ураження на протяжності та наявності в деяких спостереженнях незадовільного зв'язку між здухвинним сегментом і гілками ГАС. На практиці у хворих порівняльної групи об'єм та етапність оперативного втручання визначали на підставі результатів артеріографії або МСКТ до операції та під час оцінки ретроградного кровообігу інтраоперційно (емпірично), аналізуючи лише якісні показники (без кількісної оцінки). Таким чином, практично ангіохірург не визначає кількісних інтраопераційних критеріїв величини ретроградного кровообігу, що мають високу об'єктивну цінність для визначення хірургічної тактики.

В основній групі середній показник величини ретроградного кровообігу по ГАС становив $(81,3 \pm 3,2)$ мл/хв.
Його вважали критерієм відтермінування наступного етапу реконструкції стегно-підколінного сегмента.

Всім хворим обох клінічних груп виконали біфуркаційне аорто-стегнове алошунтування. Одночасно аортостегнове та стегно-підколінне шунтування виконали 30 (44,1\%) хворим основної групи, етапно - 38 (55,9\%); в порівняльній групі - відповідно 17 (25,4\%) та 50 (74,6\%) пацієнтам. Перевагу надавали ПТФЕ-матеріалу. При виконанні стегно-підколінного шунтування аломатеріал використовували у $37 \%$, автовену - у $63 \%$ хворих. У раньому періоді спостереження виконано 5 тромбектомій зі стегнопідколінних шунтів та 1 - із бранші протеза. Ампутацію НК виконано 4 (2,96\%) хворим; 2 - основної, 2 - порівняльної групи.

Результати виконаних оперативних втручань проаналізовані впродовж дворічного спостереження (див. maблицю).

Слід зауважити, що показник прохідності реконструйованих сегментів достовірно не відрізнявся в обох групах. Однак, враховуючи, що в основній групі 30 (44,1\%) пацієнтам виконали одночасне втручання, а в порівняльній лише 17 (25,4\%), варто принципово розрізняти отримані результати відносно структури розподілення хворих у залежності від типу виконаного втручання. Крім того, визначено показник - кількість збережених кінцівок в міжетапний період. В основній групі було 4 (5,9\%) хворих, яким виконали ампутацію НК у період очікування наступного етапу; в порівняльній групі - 8 (11,9\%). Слід зазначити, що частота виявлених кардіологічних ускладнень у хворих обох груп достовірно не відрізнялась. Так, зазначені ускладнення зафіксовані у 11 (16,2\%) пацієнтів основної групи та у $9(13,4 \%)$ - порівняльної групи. На цьому слід особливо наголосити, враховуючи більшу частоту одночасних втручань у пацієнтів основної групи. Госпітальна летальність становила 4,41\% - в основній та 4,47\% - у порівняльній групі.

\section{Обговорення}

Питання обгрунтованого розширення показань до реконструктивних операцій при багаторівневих ураженнях залишається надзвичайно гострим. За даними F. J. Veith i співавторів [6], недоцільне розширення об'єму оперативного втручання при багаторівневих ураженнях на 20 - 30\% збільшує частоту виникнення тромбозу зони оперативного втручання та на 10 - 15\% - періопераційну летальність загалом через кардіологічні ускладнення . 3 іншого боку, стандартний етапний підхід до хірургічної тактики не відповідає сучасним вимогам до причини значної частоти тромботичних ускладнень (до 12 - 17\%) та прогре- 
суючого зменшення кількості збережених кінцівок (до $10 \%)$ в міжетапний період. За висновками A. Mohapatra i співавторів [7], широке впровадження в клінічну практику інтраопераційних методів діагностики стану дистального кровообігу, а також інтраопераційного контролю функціонуючої реконструкції за допомогою УЗДС уможливить своєчасне запобігання виникненню гемодинамічної нестабільності шунта та його тромбозу. Тому ніяку одночасну багаторівневу артеріальну реконструкцію не слід виконувати без належного апаратного інтраопераційного їі контролю. Ми запропонували використовувати критерій - показник ретроградного кровообігу 80 мл/хв по ГАС як діагностичний чинник під час інтраопераційної корекції хірургічної тактики у хворих з оклюзійним ураженням черевної аорти, клубових артерій та артерій НК.

\section{Висновки}

1. Розширення показань до одночасного багаторівневого реконструктивного втручання при оклюзійному ураженні черевної аорти та артерій НК із застосуванням розробленого гемодинамічного критерію - величини ретроградного кровообігу по глибокій артерії стегна 80 мл/хв - дало змогу покращити результати оперативного лікування. Частота виникнення тромбозу шунтів в міжетапний період зменшилась 3 11,9 до 5,9\%.

2. Застосування препарату «Валаргін» в дозі 3000 мг/добу протягом 20 діб забезпечує адекватну ангіопротекцію в найближчий післяопераційний період та профілактику в подальшому прогресування атеросклерозу у разі стандартної протокольної терапії.

\section{References}

1. Branco BC, Kougias P, Braun JD, Mills JL Sr, Barshes NR. Distal vein patch use and limb events after infragenicular prosthetic bypasses. J Vasc Surg. 2018 Jul;68(1):145-152. doi: 10.1016/j.jvs.2017.11.073.

2. Wilson DG, Harris SK, Barton C, Crawford JD, Azarbal AF, Jung E, et al. Tibial artery duplex ultrasound-derived peak systolic velocities may be an objective performance measure after above-knee endovascular therapy for arterial stenosis. J Vasc Surg 2018 August;68(2):481-6. doi:10.1016/j.jvs.2017.11.092.

3. Bura Riviere A, Bouée S, Laurendeau C, Torreton E, Gourmelen J, Thomas-Delecourt F. Outcomes and management costs of peripheral arterial disease in France. J Vasc Surg. 2018 Jun;67(6):1834-43. doi: 10.1016/j. jvs.2017.09.041.

4. Tanaka A, Sandhu H K, Perlick A. Superficial femoral artery occlusion reduces aortofemoral bypass graft patency. Eur J Vasc and Endovasc Surg 2017:54(4):P-044

5. Conte MS. Bypass versus Angioplasty in Severe Ischaemia of the Leg (BASIL) and the (hoped for) dawn of evidence-based treatment for advanced limb ischemia. J Vasc Surg. 2010 May;51(5 Suppl):69S-75S. doi: 10.1016/j.jvs.2010.02.001.

6. Veith FJ, Gargiulo NiJ, Suggs WD, Lipsitz EC. Should Polytetrafluoroethylene (PTFE) Tibial and Peroneal Arterial Bypass Grafting be Used for Critical Lower Extremity Ischemia? A 30 Year-Experience. J Vasc Surg. 2015 June;61(6 Suppl):156S-157S. doi: 10.1016/j.jvs.2015.04.298.

7. Mohapatra A, Boitet A, Malak O, HenryJC, AvgerinosED, MakarounMS, et al. Peroneal bypass versus endovascular peroneal intervention for critical limb ischemia. J Vasc Surg. 2018 June. Available from: https://www. sciencedirect.com/science/article/pii/S0741521418310577. doi:10.1016/j. jvs.2018.04.049. 